\title{
UPAYA PENINGKATAN KOMPETENSI GURU DALAM MENYUSUN PERANGKAT PEMBELAJARAN MELALUI SUVERVISI AKADEMIK DI SMP NEGERI 05 KABUPATEN TEBO TAHUN AJARAN 2019/2020
}

\author{
YUSRI \\ SMP Negeri 05 Kabupaten Tebo Provinsi Jambi \\ yusriaisya66@gmail.com
}

\begin{abstract}
ABSTRAK
Penelitian ini bertujuan: 1) Untuk mengetahui langkah-langkah pelaksanaan kegiatan Supervisi Akademik dalam menyusun Perangkat Pembelajaran Rencana Pelaksanaan Pembelajaran (RPP) untuk meningkatkan kompetensi profesional guru bagi guru di SMP Negeri 05 Kabupaten Tebo dalam melaksanakan pembelajaran. 2) Untuk mengetahui peningkatan kompetensi guru di SMP Negeri 05 Kabupaten Tebo semester ganjil tahun ajaran 2019/2020 dalam Menyusun Perangkat Pembelajaran Rencana Pelaksanaan Pembelajaran (RPP) melalui kegiatan Supervisi Akademik. Subyek penelitian ini adalah semua guru SMP Negeri 05 Kabupaten Tebo semester ganjil tahun ajaran 2019/2020. Penelitian ini adalah Penelitian Tindakan Sekolah (PTS) yang terdiri dari dua siklus, setiap siklusnya meliputi tahap perencanaan, pelaksanaan, observasi, dan refleksi. Teknik analisis data yang digunakan adalah deskriptif komparatif. Dari hasil penelitian dapat disimpulkan bahwa: 1) Langkah-langkah pelaksanaan Supervisi Akademik guna meningkatkan kompetensi profesional guru dalam Menyusun RPP di SMP Negeri 05 Kabupaten Tebo adalah sebagai berikut: (a) Menyampaikan pengumuman kepada guru tentang akan dilaksanakannya kegiatan Supervisi Akademik mengenai penyusunan RPP; (b) Mempersiapkan materi bimbingan berupa pelaksanaan pembelajaran disertai simulasinya; (c) Mempersiapkan instrumen Supervisi Akademik; (d) Melaksanakan kegiatan Supervisi Akademik dengan tidak mengganggu kegiatan pembelajaran; dan e) Melaksanakan pengamatan di kelas saat dilaksanakan kegiatan pembelajaran oleh guru; dan 2) Supervisi Akademik dapat meningkatkan kompetensi profesional guru SMP Negeri 05 Kabupaten Tebo dalam menyusun RPP. Hal ini ditunjukkan dengan meningkatnya kompetensi profesional guru baik dalam tahap persiapan maupun pelaksanaan. Hal ini ditunjukkan dengan meningkatnya ketercapaian kompetensi dari sebesar 69,58 pada kondisi awal, menjadi sebesar 72,81 pada akhir tindakan Siklus 1, dan meningkat menjadi 83,13 pada tindakan Siklus II.
\end{abstract}

Kata Kunci: kompetensi guru, perangkat pembelajaran, Supervisi Akademik.

\section{ABSTRACT}

This study aims: 1) To find out the steps for implementing Academic Supervision activities in preparing the Learning Implementation Plan (RPP) to improve teacher professional competence for teachers at SMP Negeri 05 Tebo Regency in carrying out learning. 2) To find out the increase in teacher competence at SMP Negeri 05 Tebo Regency in the odd semester of the 2019/2020 academic year in Preparing Learning Implementation Plans (RPP) through Academic Supervision activities. The subjects of this study were all teachers of SMP Negeri 05 Tebo Regency in the odd semester of the 2019/2020 school year. This research is School Action Research (PTS) which consists of two cycles, each cycle includes the stages of planning, implementation, observation, and reflection. The data analysis technique used is comparative descriptive. From the results of the study it can be concluded that: 1) The steps for implementing Academic Supervision in order to improve the professional competence of teachers in preparing lesson plans at SMP Negeri 05 Tebo Regency are as follows: (a) Delivering announcements to teachers about the implementation of Academic Supervision activities regarding the preparation of lesson plans; (b) Prepare guidance materials in the form of implementation of learning accompanied by simulations; (c) Preparing Academic Supervision instruments; (d) Carry out Academic Supervision activities without disturbing learning activities; and e) Carrying out observations in the classroom when learning activities are carried out by the teacher; and 2) 
Academic Supervision can improve the professional competence of teachers of SMP Negeri 05 Tebo Regency in preparing lesson plans. This is indicated by the increasing professional competence of teachers both in the preparation and implementation stages. This is indicated by the increase in competency achievement from 69.58 in the initial condition, to 72.81 at the end of Cycle 1 action, and increased to 83.13 in Cycle II action.

Keywords: teacher competence, learning tools, Academic Supervision.

\section{PENDAHULUAN}

Pembelajaran diarahkan untuk melaksanakan tugas kekhalifaan di muka bumi dalam orientasi spiritual dan nilai-nilai Islam yang kental sebagai tugas utama manusia muslim terdidik. Dalam hal ini, diasumsikan bahwa nurani muslim terdidik benar-benar senantiasa merasa terpanggil untuk berperan menuju tingkatan yang lebih baik sesuai fitrah kemanusiaannya. Dalam setiap aspek kehidupan akan melahirkan manusia yang berkualitas. Pendidikan diharapkan untuk dapat mengantarkan peserta didik mencapai kebahagiaan dalam wujud nyata, dan kembali kepada fitrah kemanusiaan yang sesungguhnya (Zein, 2016). Kualitas pendidikan sering menjadi isu sentral dan yang sering menjadi sorotan adalah guru atau pendidik, walaupun disadari bahwa berbagai komponen turut mempengaruhi, seperti: kurikulum, Siswa dan media pembelajaran. Hal ini sangat dimungkinkan mengingat guru merupakan perencana sekaligus pelaksana pembelajaran, sehingga guru selalu dituntut meningkatkan kinerjanya demi terciptanya proses pembelajaran yang efektif demi pencapaian tujuan pendidikan nasional. Proses pembelajaran merupakan inti dari proses pendidikan secara keseluruhan dengan guru sebagai pemegang peranan utama. Guru merupakan aktor utama dalam pelaksanaan proses pembelajaran baik ia sebagai pengajar, pengelola dan perananperanan lain yang diembannya (Idzhar, 2016). Guru sebagai salah satu komponen pendidikan memberikan konsekuensi pada perlunya dibekali kemampuan secara profesional dalam melaksanakan tugas. Rasa tanggung jawab atau pengabdian dalam pelaksanaan tugas demi peningkatan kualitas pendidikan sangat diperlukan karena dalam sehari-hari, guru sekolah lain dituntut sebagai pendidik sekaligus sebagai pengajar. Untuk mewujudkan hal tersebut dibutuhkan peran serta dari semua pihak, antara lain adalah lembaga pendidikan. Berbagai upaya terlah dilakukan oleh lembaga pendidikan utuk meningkatkan mutu pendidikan, di sisi lain untuk meningkatkan kualitas pendidikan diadakannya tes setiap akhir semester untuk mengetahui prestasi siswa dalam menyerap materi pelajaran yang diberikan serta untuk mengetahui sejauh mana keberhasilan guru dalam menyajikan materi pelajaran dalam kurung waktu tertentu sesuai dengan kurikulum (Kirom, 2017).

Peran guru dalam mentransformasikan input-input pendidikan sangat penting. Hal ini tidak terlepas dari adanya sistem persekolahan yang mencakup input - proses - output, di mana guru sebagai salah satu faktor input yang berperan penting dalam proses untuk dapat menghasilkan output sesuai dengan apa yang diharapkan (Khofiatun, dkk, 2016). Agar dapat melaksanakan proses yang berkualitas, guru dituntut untuk melaksanakan tugasnya sesuai dengan standar kerja guru yang telah ditetapkan. Pasal 35 ayat (1) UU No. 14/ 2005 menyebutkan bahwa beban kerja guru mencakup kegiatan pokok yaitu merencanakan pembelajaran, melaksanakan pembelajaran, menilai hasil pembelajaran, membimbing dan melatih peserta didik, serta melaksanakan tugas tambahan (Arman, 2017). Amanat yang terkandung dalam pasal tersebut mengimplikasikan bahwa sebenarnya ada lima tuga pokok yang harus dilaksanakan oleh guru. Akan tetapi, dari kelima tugas pokok tersebut hanya ada tiga jenis tugas yang berupa kegiatan tatap muka, yaitu melaksanakan pembelajaran, menilai hasil pembelajaran, serta membimbing dan melatih peserta didik. Sedangkan tugas perencanaan pembelajaran yang merupakan salah satu tugas pokok sering terabaikan karena tidak berkaitan dengan tatap muka (Astawa, 2017).

Perencanaan pembelajaran yang mencakup kegiatan mengkaji kurikulum, menyusun silabus, strategi pembelajaran, sumber belajar yang digunakan dan satuan kegiatan pembelajaran sebenarnya justru merupakan hal terpenting karena perencanaan merupakan 
landasan dari pelaksanaan yang dilakukan. Akan tetapi hal ini sering terabaikan karena banyak guru yang menganggap bahwa perencanaan pembelajaran dapat dilakukan dengan mencontoh dokumen-dokumen yang disusun sekolah lain. Hal ini berdampak pada banyaknya perencanaan yang tidak sesuai dengan kebutuhan sekolah (Nadia, dkk, 2020).

Hal yang sama terjadi pula di SMP Negeri 05 Kabupaten Tebo Provinsi Jambi. Sebagian besar guru hanya melakukan copy dan paste dari sekolah lain dalam penyusunan perencanaan pembelajaran sehingga mereka kurang memahami kebutuhan sekolah. Kondisi tersebut berdampak pada sering tidak sesuainya perencanaan dengan pelaksanaan yang dilakukan di kelas. Keadaan yang kurang menggembirakan tersebut didukung oleh hasil penilaian pada tiga aspek kinerja guru yang meliputi perencanaan pembelajaran, pelaksanaan pembelajaran, dan penilaian pembelajaran. Hasil penilaian menunjukkan bahwa perencanaan pembelajaran yang disusun oleh para guru sudah baik yang ditunjukkan dengan rata-rata skor sebesar 35.38 dari skor ideal sebesar 50 atau dengan tingkat ketercapaian kinerja rata-rata sebesar $70.75 \%$. Hasil penilaian pada aspek perencanaan pembelajaran yang sudah baik tersebut ternyata tidak ditunjang dengan kompetensi yang sebanding dalam pelaksanaan. Hal ini ditunjukkan dengan hasil penilaian pada aspek pelaksanaan di mana diperoleh skor rata-rata sebesar 64.75 dari skor ideal sebesar 100 atau dengan tingkat ketercapaian kompetensi sebesar $64.75 \%$.

Penilaian pada aspek kompetensi guru dalam penilaian juga tidak mencerminkan tingginya kemampuan guru dalam kemampuan penyusunan perencanaan pembelajaran. Hal ini ditunjukkan dengan hasil penilaian pada aspek penilaian di mana diperoleh skor rata-rata sebesar 70.38 dari skor ideal sebesar 110 atau dengan tingkat ketercapaian kompetensi sebesar 63.98\%. Secara keseluruhan, hasil penilaian kompetensi guru pada ketiga aspek penilaian kompetensi guru SMP Negeri 05 Kabupaten Tebo masih belum optimal. Hal ini ditunjukkan dengan skor rata-rata yang diperoleh baru mencapai 170.5 dari skor ideal sebesar 260 atau dengan tingkat ketercapaian kompetensi sebesar $65.58 \%$

Kondisi tersebut perlu menjadi perhatian bagi Kepala Sekolah untuk melakukan tindakan perbaikan. Tindakan perbaikan yang dapat dilakukan Kepala Sekolah adalah melalui kegiatan Supervisi Akademik.

Salah satu upaya yang dirasakan paling efektif dalam rangka meningkatkan kompetensi guru adalah mengoptimalkan peran kepala sekolah melalui supervisi. Supervisi pendidikan didefinisikan sebagai proses pemberian layanan bantuan profesional kepada guru untuk meningkatkan kemampuannya dalam melaksanakan tugas-tugas pengelolaan proses pembelajaran secara efektif dan efisien (Rismiati, 2018).

Sering dijumpai adanya seorang kepala sekolah dalam melaksanakan supervisi akademik hanya datang ke sekolah dengan membawa instrumen pengukuran unjuk kerja. Kemudian masuk ke kelas melakukan pengukuran terhadap unjuk kerja guru yang sedang mengajar. Setelah itu, selesailah tugasnya, seakan-akan supervise akademik sama dengan pengukuran guru dalam pelaksanaan pembelajaran (Anggraini, 2017). Perilaku supervisi akademik sebagaimana digambarkan di atas merupakan salah satu contoh perilaku supervisi akademik yang salah. Perilaku supervisi akademik yang demikian tidak akan memberikan banyak pengaruh terhadap peningkatan kualitas unjuk kerja guru dalam mengelola proses pembelajaran. Seandainya memberikan pengaruh, pengaruhnya sangat kecil artinya bagi peningkatan kualitas unjuk kerja guru dalam mengelola proses pembelajaran.

Meskipun demikian, supervisi akademik tidak bisa terlepas dari penilaian unjuk kerja guru dalam mengelola pembelajaran. Apabila di atas dikatakan, bahwa supervisi akademik merupakan serangkaian kegiatan membantu guru mengembangkan kemampuannya mengelola proses pembelajaran, maka menilai unjuk kerja guru dalam mengelola proses pembelajaran merupakan salah satu kegiatan yang tidak bisa dihindarkan prosesnya (Nasution, 2019). Penilaian unjuk kerja guru dalam mengelola proses pembelajaran sebagai suatu proses pemberian estimasi kualitas unjuk kerja guru dalam mengelola proses pembelajaran, merupakan bagian integral dari serangkaian kegiatan supervisi akademik. Apabila dikatakan 
bahwa supervise akademik merupakan serangkaian kegiatan membantu guru mengembangkan kemampuannya, maka dalam pelaksanaannya terlebih dahulu perlu diadakan penilaian kemampuan guru, sehingga bisa ditetapkan aspek yang perlu dikembangkan dan cara mengembangkannya (Bahri, 2014).

Bertolak dari latar belakang masalah tersebut, peneliti tertarik mengangkat penelitian dengan judul "Upaya Peningkatan Kompetensi Guru Dalam Menyusun Perangkat Pembelajaran Melalui Suvervisi Akademik di SMP Negeri 05 Kabupaten Tebo Tahun Ajaran 2019/2020".

\section{METODE PENELITIAN}

Penelitian yang dilakukan adalah Penelitian Tindakan Sekolah (PTS). Arikunto (2010) menjelaskan proses penelitian dilaksanakan dua siklus, setiap siklusnya terdiri dari empat tahap yaitu: (1) perencanaan, (2) pelaksanaan, (3) pengamatan, (4) refleksi. Penelitian dilaksanakan di SMP Negeri 05 Kabupaten Tebo Provinsi Jambi Semester Ganjil Tahun Ajaran 2019/2020. Subjek penelitian adalah guru SMP Negeri 05 Kabupaten Tebo, baik yang sudah berstatus pegawai negeri sipil ataupun pegawai honorer yang berjumlah 29 Orang. Penelitian ini dilakukan selama 2 bulan dari September sampai dengan November 2019.

Teknik pengumpulan data yang digunakan melalui teknik non-tes, serta pengumpulan data kualitatif yang diperoleh dari observasi atau pengamatan, wawancara, dan dokumen. Penelitian ini dikatakan berhasil apabila $>70 \%$ guru sudah mempunyai kompetensi dengan kategori BAIK.

\section{HASIL DAN PEMBAHASAN}

Peran guru dalam mentransformasikan input-input pendidikan sangat penting. Hal ini tidak terlepas dari adanya sistem persekolahan yang mencakup input - proses - output, di mana guru sebagai salah satu faktor input yang berperan penting dalam proses untuk dapat menghasilkan output sesuai dengan apa yang diharapkan, beberapa guru di SMP Negeri 05 Kabupaten Tebo masih banyak yang belum memiliki kompetensi dalam menyusun RPP. Berikut rekap hasil penilaian kualitas RPP pada kondisi awal.

Tabel 1. Hasil Penilaian Kualitas RPP Kondisi Awal

\begin{tabular}{ccccc}
\hline Tingkat Kompetensi & Kategori & Frekuensi & Presen-tase & Rata-Rata \\
\hline $85-100 \%$ & Sangat baik & 5 & $16,66 \%$ & $2502,5: 29=69,51$ \\
$75-85 \%$ & Baik & 8 & $30,55 \%$ & \\
$65-75 \%$ & Cukup & 6 & $16,66 \%$ & Kategori Cukup \\
$<65 \%$ & Kurang & 10 & $27,77 \%$ & \\
\hline & JUMLAH & 29 & & $100 \%$ \\
\hline
\end{tabular}

Tabel 2. Hasil Pengamatan Guru dalam Menyusun RPP Kondisi Awal

\begin{tabular}{llcll}
\hline Tingkat Kompetensi & Kategori & Frekuensi & $\%$ & Rata-Rata \\
\hline $85-100 \%$ & Sangat baik & 8 & $27,77 \%$ & $2507,5: 29$ \\
$75-85 \%$ & Baik & 0 & $0 \%$ & $=69,65$ \\
$65-75 \%$ & Cukup & 11 & $41,66 \%$ & Kategori \\
$<65 \%$ & Kurang & 11 & $30,55 \%$ & Cukup \\
\hline JUMLAH & & \multicolumn{2}{c}{29} & $100 \%$ \\
\hline
\end{tabular}

\section{Siklus I}

Perencanaan, Perencanaan adalah langkah awal yang dilakukan oleh penulis saat akan memulai tindakan. Agar perencanaan mudah dipahami dan dilaksanakan oleh penulis yang 
akan melakukan tindakan, maka penulis membuat rencana tindakan diantaranya Peneliti merencanakan waktu, sasaran, dan cara mengobservasi selama proses Supervisi Akademik, merencanakan metode Supervisi Akademik dan perencanaan tindak lanjut. Observer atau pengamat yang dilibatkan dalam penelitian diambil dari rekan sejawat. Pemilihan dua observer berbeda dimaksudkan agar data yang diperoleh reprensentatif. Peneliti juga mempersiapkan instrumen hasil Supervisi Akademik, kemudian menganalisis hasil Supervisi Akademik tersebut. Perencanaan dilakukan kurang lebih 1 minggu. Tidak ada kendala yang berarti yang dihadapi peneliti selama menyusun perencanaan tindakan sekolah ini.

Pelaksanaan, Siklus I dilakukan dalam tiga pertemuan. Dalam pelaksanaan ini melibatkan 29 orang guru yang diobservasi. Tindakan pertama seluruh guru dikumpulkan dalam satu ruangan kemudian diberikan Supervisi Akademik terutama dalam penguasaan menyusun Rencana Pelaksanaan Pembelajaran (RPP). Pembinaan ditekankan pada proses penyusunan RPP baik dari materi maupun media yang akan digunakan oleh guru dalam mengajar, guru dibimbing untuk menyusun RPP dengan benar. Selain itu guru juga dibimbing dalam menggunakan dan pemanfaatan sumber dan media belajar. Selama pelaksanaan, observer mengamati jalannya kegiatan.

Setelah melakukan serangkaian kegiatan Supervisi Akademik pada masing-masing guru kemudian guru diberi kesempatan untuk membuat RPP sesuai dengan pengarahan yang telah diberikan, setelah selesai guru diberikan kusioner untuk diisi. Lembar kuesioner dan RPP yang telah diisi dianalisis. Tidak ada kendala yang berarti yang dihadapi peneliti selama proses pelaksanaan ini.

Observasi, Pada proses pengamatan atau observasi dilakukan oleh peneliti dengan menggunakan lembar observasi selama satu bulan (satu siklus), untuk semua guru yang berjumlah 36 orang.

Selama melakukan serangkaian kegiatan Supervisi Akademik, guru masih banyak yang terlihat malasmalasan dalam mengikuti kegiatan Supervisi Akademik. Rekapitulasi hasil observasi guru dalam menyusun RPP pada siklus I dapat dilihat pada Tabel 3.

Tabel 3. Hasil Pengamatan Guru dalam Menyusun RPP Siklus I

\begin{tabular}{|c|c|c|c|c|}
\hline Tingkat Kompetensi & Kategori & Frekuensi & $\%$ & Rata-Rata \\
\hline $85-100 \%$ & Sangat baik & 3 & $8,33 \%$ & 2550:29 \\
\hline $75-85 \%$ & Baik & 9 & $33,33 \%$ & $=70,83$ \\
\hline $65-75 \%$ & Cukup & 9 & $33,33 \%$ & Kategori \\
\hline$<65 \%$ & Kurang & 8 & $25 \%$ & Cukup \\
\hline \multicolumn{2}{|c|}{ JUMLAH } & 29 & \multicolumn{2}{|r|}{$100 \%$} \\
\hline
\end{tabular}

Berdasarkan Tabel 3 dapat dilihat bahwa hasil observasi guru pada saat menyusun RPP pada siklus I, rata-rata yang diperoleh sebesar 70,83 dengan kategori cukup. Rekapitulasi hasil penilaian kualitas RPP pada siklus I dapat dilihat pada Tabel 4.

Tabel 4. Hasil Penilaian Kualitas RPP Siklus I

\begin{tabular}{|c|c|c|c|c|}
\hline Tingkat Kompetensi & Kategori & Frekuensi & $\%$ & Rata-Rata \\
\hline $85-100 \%$ & Sangat baik & 0 & $0 \%$ & $2692,5: 29$ \\
\hline $75-85 \%$ & Baik & 20 & $66,66 \%$ & $=74,79$ \\
\hline $65-75 \%$ & Cukup & 6 & $25 \%$ & Kategori \\
\hline$<65 \%$ & Kurang & 3 & $8,33 \%$ & Cukup \\
\hline \multicolumn{2}{|c|}{ JUMLAH } & 29 & & $100 \%$ \\
\hline
\end{tabular}


Berdasarkan Tabel 4 dapat dilihat bahwa rata-rata nilai kualitas RPP yang dibuat oleh guru pada siklus I sebesar 74,79 yang termasuk kategori cukup.

Refleksi, Tahap refleksi yaitu menganalisis hasil pengamatan, dan megevaluasi kegiatan Supervisi Akademik yang baru saja dilaksanakan. Refleksi dilakukan untuk mengetahui kekurangan atau kendala pada siklus I, sehingga dapat diperoleh kesimpulan tentang bagian yang perlu diperbaiki dan bagian yang telah mencapai tujuan penelitian. Pelaksanaan Supervisi Akademik bagi guru untuk meningkatkan kompetensi guru dalam menyusun RPP pada siklus I dapat dikatakan cukup baik namun masih ada beberapa kendala, yaitu: a) Guru masih banyak yang belum paham tentang penyusunan RPP yang benar. b) Partisipasi guru dalam kegiatan Supervisi Akademik masih belum terlihat, masih banyak guru yang enggan bertanya pada supervisor. c) Ketika guru diberi tugas untuk menyusun RPP, guru enggan untuk mengerjakan.

\section{Siklus II}

Perencanaan, Tindakan siklus II merupakan upaya perbaikan terhadap tindakan siklus I. Tahapan yang dilakukan sama dengan tahapan pada siklus I, namun pada siklus II ada beberapa hal yang perlu ditekankan dan ditambahkan, yaitu: Pertama, sebelum melaksanakan Supervisi Akademik, supervisor menekankan agar guru lebih berperan aktif dalam kegiatan Supervisi Akademik agar kemampuan guru dalam menyusun RPP dapat meningkat, Kedua, supervisor memberitahukan kepada guru bahwa guru tidak usah enggan untuk bertanya apabila ada sesuatu yang belum dipahami tentang menyusun RPP.

Pelaksanaan, Melaksanakan kegiatan sesuai dengan perencanaan tindakan siklus II. Dalam pelaksanaan ini melibatkan 29 orang guru yang diobservasi. Tindakan pertama, seluruh guru dikumpulkan dalam satu ruangan kemudian diberikan Supervisi Akademik terutama dalam penguasaan menyusun Rencana Pelaksanaan Pembelajaran (RPP). Pembinaan ditekankan pada proses penyusunan RPP baik dari materi maupun media yang akan digunakan oleh guru dalam mengajar, guru dibimbing untuk menyusun RPP dengan benar. Selain itu guru juga dibimbing dalam menggunakan dan pemanfaatan sumber dan media belajar. Selama pelaksanaan, observer mengamati jalannya kegiatan Supervisi Akademik.

Setelah melakukan serangkaian kegiatan Supervisi Akademik pada masing-masing guru kemudian gurudiberi kesempatan untuk membuat RPP sesuai dengan pengarahan yang telah diberikan, setelah selesai guru diberikan kusioner untuk diisi. Lembar kuesioner dan RPP yang telah diisi dianalisis. Supervisi Akademik pada siklus II berjalan dengan lancar.

Observasi, Selama melakukan serangkaian kegiatan Supervisi Akademik, guru terlihat antuasias dalam menyimak, bertanya, dan mengumpulkan materi untuk menyusun RPP. Rekapitulasi hasil observasi guru dalam menyusun RPP pada siklus II dapat dilihat pada Tabel 5 .

Tabel 5. Hasil Pengamatan Guru dalam Menyusun RPP Siklus II

\begin{tabular}{ccccc}
\hline Tingkat Kompetensi & Kategori & Frekuensi & $\%$ & Rata-Rata \\
\hline $85-100 \%$ & Sangat baik & 15 & $44,44 \%$ & $2892: 29$ \\
$75-85 \%$ & Baik & 11 & $30,55 \%$ & $=80,35$ \\
$65-75 \%$ & Cukup & 3 & $19,44 \%$ & Kategori \\
$<65 \%$ & Kurang & 2 & $5,55 \%$ & Baik \\
\hline & JUMLAH & 29 & & $100 \%$
\end{tabular}

Berdasarkan Tabel 5 dapat dilihat bahwa hasil observasi guru pada saat menyusun RPP pada siklus II, rata-rata yang diperoleh sebesar 80,35 dengan kategori baik. Rekapitulasi hasil penilaian kualitas RPP pada siklus II dapat dilihat pada tabel 6.

Tabel 6. Hasil Penilaian Kualitas RPP Siklus II

$\begin{array}{lllll}\text { Tingkat Kompetensi } & \text { Kategori } & \text { Frekuensi } & \% & \text { Rata-Rata }\end{array}$




\begin{tabular}{ccccc}
\hline $85-100 \%$ & Sangat baik & 21 & $58,33 \%$ & $3042,5: 29$ \\
$75-85 \%$ & Baik & 8 & $36,11 \%$ & $=84,51$ \\
$65-75 \%$ & Cukup & 1 & $5,55 \%$ & Kategori \\
$<65 \%$ & Kurang & 0 & $0 \%$ & Cukup \\
\hline \multicolumn{2}{r}{ JUMLAH } & 29 & \multicolumn{2}{c}{$100 \%$} \\
\hline
\end{tabular}

Berdasarkan Tabel 6 dapat dilihat bahwa rata-rata nilai kualitas RPP yang dibuat oleh guru pada siklus II sebesar 84,21 yang termasuk kategori baik.

Refleksi, dilaksanakan setiap akhir siklus, dimaksudkan untuk mengetahui berbagai masalah yang muncul pada pelaksanaan tindakan siklus II. Kekurangan pada siklus I telah diperbaiki pada kegiatan Supervisi Akademik siklus II. Pada siklus II nilai kompetensi guru dalam menyusun Rencana Pelaksanaan Pembelajaran (RPP) peningkatan dari nilai siklus sebelumnya. Peningkatan kompetensi guru dalam menyusun RPP dapat dilihat pada Tabel 7.

Tabel 7. Pencapaian Kompetensi Siklus II

\begin{tabular}{lccc}
\hline \multicolumn{1}{c}{ Keterangan } & Prasiklus & Siklus I & Siklus II \\
\hline Rata-rata Penilaian Kualitas RPP & 69,51 & 70,83 & 84,51 \\
Rata-rata Pengamatan Guru dalam Menyusun RPP & 69,65 & 74,79 & 80,35 \\
Rata-Rata Pencapaian Kompetensi & 69,58 & 72,81 & 83,13 \\
\hline
\end{tabular}

Berdasarkan Tabel 7 dapat diketahui sebelum dilakukan tindakan (prasiklus) nilai kompetensi guru dalam menyusun RPP sebesar 65,50 dengan kategori cukup setelah tindakan siklus I mengalami peningkatan menjadi 73,25 dengan kategori cukup dan kembali mengalami peningkatan pada tindakan siklus II menjadi 82,25 dengan kategori baik.

\section{KESIMPULAN}

Melalui kegiatan Supervisi Akademik dapat meningkatkan kompetensi guru SMP Negeri 05 Kabupaten Tebo dalam menyusun Rencana Pelaksanaan Pembelajaran (RPP). Langkah-langkah yang dilakukan dalam pelaksanaan Supervisi Akademik guna meningkatkan kompetensi guru SMP Negeri 05 Kabupaten Tebo dalam menyusun Rencana Pelaksanaa Pembelajaran (RPP), yaitu: (a) menyampaikan pengumuman kepada guru tentang akan dilaksanakannya kegiatan Supervisi Akademik mengenai penyusunan RPP; (b) mempersiapkan materi bimbingan berupa pelaksanaan pembelajaran disertai simulasinya; (c) Mempersiapkan instrumen; (d) melaksanakan kegiatan Supervisi Akademik dengan tidak mengganggu kegiatan pembelajaran; dan e) melaksanakan pengamatan di kelas saat dilaksanakan kegiatan pembelajaran oleh guru.

\section{DAFTAR PUSTAKA}

Anggraini, S. (2017). Peran supervisi bk untuk meningkatkan profesionalisme guru Bk. In Prosiding Seminar Bimbingan dan Konseling (Vol. 1, No. 1, pp. 332-341).

Arman, A. (2017). Upaya peningkatan kompetensi guru dalam menyusun rencana pelaksanaan pembelajaran melalui supervisi akademik Kepala Sekolah di SMAN 1 Lembah Melintang Kabupaten Pasaman Barat. Jurnal Manajemen Pendidikan, 1(1).

Astawa, I. B. M. (2017). Memahami Kewajiban Guru Dalam Menyusun Rencana Pelaksanaan Pembelajaran (RPP). Media Komunikasi Geografi, 16(1).

Bahri, S. (2014). Supervisi akademik dalam peningkatan profesionalisme guru. Visipena, 5(1), $100-112$.

Idzhar, A. (2016). Peranan guru dalam meningkatkan motivasi belajar siswa. Jurnal office, 2(2), 221-228. 
Khofiatun, K., \& Ramli, M. (2016). Peran Kompetensi Pedagogik Guru Dalam Pembelajaran Tematik Di Sekolah Dasar. Jurnal Pendidikan: Teori, Penelitian, dan Pengembangan, 1(5), 984-988.

Kirom, A. (2017). Peran guru dan peserta didik dalam proses pembelajaran berbasis multikultural. Jurnal Al-Murabbi, 3(1), 69-80.

Nadia, H., Yansyah, Y., \& Murtiningsih, T. (2020). Pelatihan Pembuatan RPP Menggunakan Metode 4 C'S Bagi Guru-Guru MGMP Bahasa Inggris Kalimantan Selatan. Jurnal Pemberdayaan: Publikasi Hasil Pengabdian kepada Masyarakat, 4(3), 339-346.

Nasution, T. A. (2019). Peran Supervisi Pendidikan dalam Meningkatkan Mutu Pendidikan di Indonesia.

Rismiati, H. (2018). PENINGKATAN KOMPETENSI GURU DALAM MENYUSUN RPP MELALUI SUPERVISI AKADEMIK BERKELANJUTAN. Ideguru: Jurnal Karya Ilmiah Guru, 3(1), 33-39.

Zein, M. (2016). Peran guru dalam pengembangan pembelajaran. Jurnal Inspiratif Pendidikan, 5(2), 274-285. 